\title{
MEDEA DE EURÍPIDES: LA “ATÉTESIS” DE VERSOS Y LA CONSTRUCCIÓN GRADUAL DE LA VENGANZA
}

\author{
Pablo A. CAVAllero
}

UBA- CONICET

El trabajo propone revisar la "atétesis" y las enmiendas aplicadas a diversos pasajes de Medea, sosteniendo que muchas de ellas son innecesarias si se entiende la venganza como una decisión cuyo método no está establecido desde el comienzo sino que se construye gradualmente. Esa gradación provoca aparentes contradicciones. Se consideran los siguientes pasajes cuestionados: 40-43, 87, 261-2, 361-2, 366-7, 468, 725-6, 782, 785-6, 923-4, 1056-1080, 1121, 1220-1, 1316, 1359, 1387; también todo el desarrollo de la obra para probar la acción de aquellos en la construcción gradual de la venganza; se tiene en cuenta el uso léxico en el interior de la pieza. En este proceso, los pasajes aquí analizados y cuestionados por la crítica en cuanto a su autenticidad resultan no sólo defendibles sino necesarios para establecer esa graduación que se verifica en la estructura interna, en las imágenes y en la construcción del crimen.

Palabras-clave: Medea; ecdótica; crítica textual; estructura; léxico
The work proposes to reexamine the athetesis and the emendations which were applied to diverse passages of Euripides' Medea, asserting that many of these are not necessary, if one understands the revenge as a decision whose method is not established from the beginning, but it is constructed gradually. This gradation provokes apparent contradictions. They are considered the following controverted passages: 40-43, 87, 261-2, 361-2, 366-7, 468, 725-6, 782, 785-6, 923-4, 1056-1080, 1121, 1220-1, 1316, 1359, 1387; and also all the play development, in order to prove the effect of those in the gradual construction of the revenge; it is taken into account the vocabulary use in the inside of the play. In this process, the passages here analysed, and discussed by the critics about his authenticity, result defensible and necessary to establish the graduation, which is verified in the inside structure, in the images and in the construction of the crime.

Keywords: Medea; ecdotique; textual criticism; structure; vocabulary

El texto de la Medea de Eurípides, conservado en cinco códices de los siglos XII-XIV y parcialmente en tres papiros del siglo II a. C., I a. C. y V d. C., ha sido objeto de cuestionamientos por parte de la crítica, la cual marcó pasajes como pasibles de ser considerados espurios. Francisco Rodríguez Adrados realizó y publicó un estudio sobre tales pasajes, con las opiniones 
que fundaban su establecimiento del texto ${ }^{1}$. Algunos de esos loci se vinculan con el tema de la venganza que Medea quiere perpetrar contra sus enemigos $^{2}$. Deseamos aquí retomar el análisis de esos lugares y volver a discutir el aspecto de la construcción de la venganza que, para algunos críticos, Medea tiene resuelta desde el comienzo y que para nosotros, en cambio, está resuelta en tanto decisión pero no en tanto método, de modo que se construye gradualmente a lo largo del desarrollo dramático.

Con este fin, deberemos analizar las diversas instancias de la pieza y partir de un esquema estructural, más allá de la sucesión de componentes formales (prólogo, párodo, episodios, estásimos, etc.). Una estructuración interna, vinculada netamente con el personaje central y con el tema que nos ocupa es la que surge de la presencia de Medea:
A: $1-95$
protagonismo aludido: Medea no está en escena, no se la ve ni se la oye, pero se habla de ella (prólogo)
B: 96-213 protagonismo en off: Medea no está en escena ni se la ve, pero se oyen sus quejas (prólogo-párodo) ${ }^{3}$.
C: 214-1250 protagonismo visible: Medea sale a escena y permanece constantemente en ella (episodios).
D: 1251-1316 protagonismo aludido: se habla de ella y se percibe su accionar (quinto estásimo; sexto episodio).
E: 1317-1419 protagonismo apoteótico: justifica su accionar desde la mexané (sexto episodio; éxodo).

De una u otra manera, sea por alusión, presencia, algún modo de percepción no visible o por un modo de divinización, Medea domina el desarrollo de la acción y, consecuentemente, la escena. Mediante estas diversas formas de protagonismo va construyendo su acción, que es básicamente la venganza.

Toda venganza tiene una motivación. En el caso de Medea, la motivación

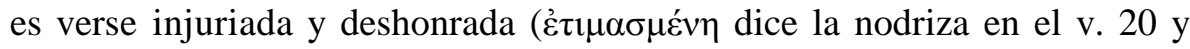

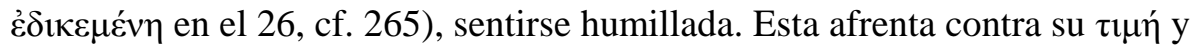

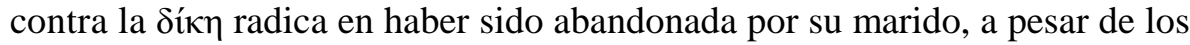

Cf. Rodríguez Adrados 1993.

2 Medea expresa su deseo de venganza con el giro díken antiteísasthai (261), díken teísein $(767,802)$. En 1298 Jasón usa dósei díken, refiriéndose al castigo que merece Medea, y teísomai díken en 1316. Medea alude también a su venganza con el término alástor (1059), que el coro retoma en 1260 y Jasón en 1333. No hay ocurrencias del vocablo némesis.

3 Respecto de la riqueza dramática del sector 1-213 y el dominio escénico de Medea, cf. Martina 1993. 
pactos contraídos con garantía divina ${ }^{4}$, lo cual constituye una traición ${ }^{5}$, y en haber sido reemplazada por otra mujer que queda por encima de ella ${ }^{6}$; para Medea, si ella no se vengara de alguna manera, sería el hazmerreír de sus enemigos $(383,404,797,1049,1355,1362)$, una mujer cualquiera sin las actitudes heroicas y masculinas de su carácter ${ }^{7}$, un personaje de comedia costumbrista, no una heroína trágica que, voluntariamente y a sabiendas de la desgracia que le espera, afronta un proceder que por su propio carácter no puede eludir.

El prólogo ofrece una especie de síntesis-anticipo de la tragedia, pues si bien presenta los datos necesarios para plantear el asunto o situación básica, también da a entender que el carácter de Medea es capaz de todo y sugiere líneas posibles de acción. Si Medea yace ayuna y en llanto (24-25) y no aparta del suelo su mirada (27-28), no escucha ningún consejo ${ }^{8}$ : es inconmovible

4 Sobre el tema del divorcio cf. nuestro trabajo «Actualidad humana de la Medea de Eurípides: el tema del divorcio», en vías de publicación; Borges 1987, Buis 2001. Sobre el peso de la divinidad cf. Kovacs 1993.

5 Sobre injuria y traición cf. Rodríguez Cidre 2000.

6 Aunque algunos críticos opinan que esta pieza está centrada en cuestiones domésticas y carece de orientación política, pensamos que esto último no es así: Eurípides, a través del asunto de esta tragedia, está criticando también la discriminación social y legal de la mujer, ciertos defectos de las leyes y costumbres relativas al matrimonio y cómo ellas afectan negati-

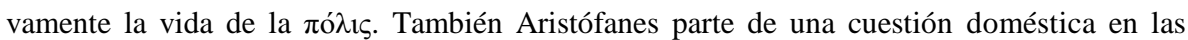
deudas de Strepsiades, pero Nubes, con su tema de la educación, tiene gran trascendencia política. Véase nuestro trabajo «Querer-poder-deber en el Dýskolos de Menandro. La trascendencia política de la ética familiar», Argos 22, 1998, pp. 33-49. Fartzoff 1996 sostiene que el vocabulario relativo al poder y a lo tiránico no tiene significación política sino que se aplica a

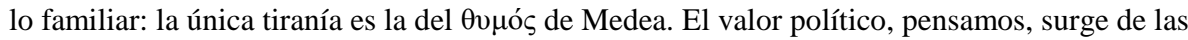
consecuencias que los sucesos tienen para la sociedad más allá del caso particular.

7 Ya se han señalado en Medea la presencia de valores heroicos y masculinos, como el de la $\tau \mu$ ń. Hay masculinización de Medea también por otros rasgos, como su lenguaje político, su habilidad retórico-judicial, el empuñar la espada; en el uso activo de $\gamma \alpha \mu \varepsilon ́ \omega$ con sentido irónico (489), el de $\sigma \pi \varepsilon ́ p \mu \alpha$ en 816 y el de $\varphi v ́ \omega$ transitivo en 1241, normalmente aplicados a varones. Tiene similitudes con las figuras de Ayante (la importancia de la deshonra, la idea de suicidio) y de Clitemnestra (el asesinato; el ser llamada odiosa, leona y Escila). Para Segal 1996 p. 18, los rasgos heroicos de Medea cuestionan el $\tilde{\eta} \theta$ o Heracles eran guerreros pero útiles a la sociedad; Medea cuestiona incluso el valor del soldado frente a la maternidad (p. 29). Para Boedeker 1997 Medea se asimila a sus enemigos para destruirlos; de ahí surgiría su masculinización heroica. Frente a esto, se ha visto una feminización de Jasón (Segal 1996 pp. 39 s.).

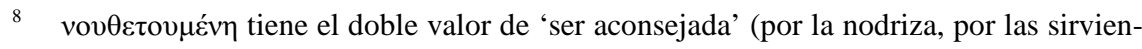
tas) y de 'tener algo en mente' (meditar sobre su situación). Por estar ensimismada, Medea no 
como una roca o un oleaje (28-29); se arrepiente de la traición perpetrada contra su familia y su patria (31-35); no disfruta el ver a sus hijos (36): el motivo de todo esto es que los hijos son el fruto de eso que ahora le causa dolor, su marido y su propia traición por amor a él. La culminación de esta presentación son los vv. 44-45, cuando la nodriza dice "es tremenda; no fácilmente, al poner enemistad con ella, alguien se llevará la bella victoria", lo cual presagia el triunfo de Medea en su lucha.

Inmediatamente antes de esta culminación aparece el primer locus discutido. Page condena los vv. 38-43; otros, los vv. 40-43 ${ }^{9}$. El problema surge cuando la nodriza expresa su temor ante todo lo descrito:

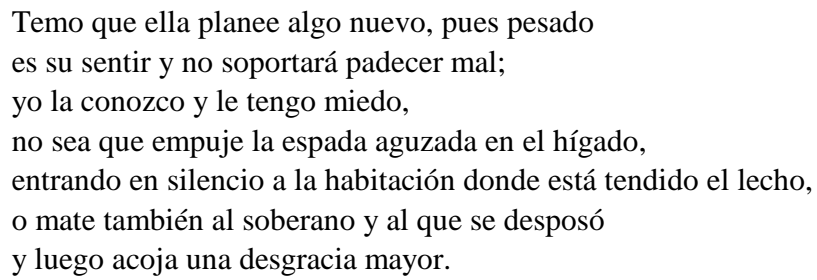

El pasaje plantea como temor de la nodriza: 1) que Medea se suicide; 2) que mate a sus enemigos, destinatario expresado de un modo ambiguo al

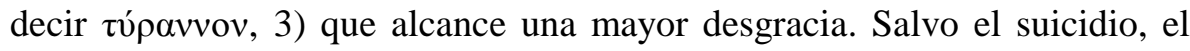
resto es ambiguo: para algunos, teme que mate a Creonte y a Jasón, en tanto negociantes responsables del agravio contra Medea; para otros, teme que

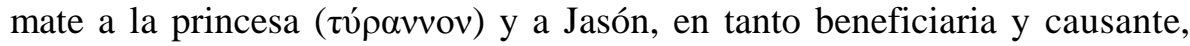

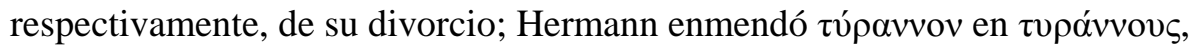
para incluir a Creonte y a su hija conjuntamente. Sin embargo, la expresión ambigua podría tener la ventaja de aludir a ambos de modo difuso. El tercer temor de la nodriza también es ambiguo, pues "una desgracia mayor" puede ser algún otro crimen o un castigo que resulte para Medea más penoso que el abandono de Jasón. La razón de suprimir estos versos es que 40-41 se repiten, con cambio de persona verbal y modo y con reemplazo de $\mu$ ì por $\grave{\eta}^{10}$, en 379-380, ya en el primer episodio, cuando en un monólogo Medea, no la nodriza, discurre sobre el modo de vengarse: en esta ocasión, Medea ve la posibilidad de atravesar con la espada a sus enemigos; es decir, ya no

escucha a nadie, como si fuera una piedra o un mar. Sobre estas comparaciones y el papel de la nodriza cf. Rodríguez Cidre 1998.

9 Nauck los suprimió; Méridier los conserva.

10 La aparición de $\ddot{\eta}$, en correlación con $\pi$ ó $\varepsilon \rho \rho v$ de 378 impide que puedan suprimirse 379-380. 
se trata allí de suicidio sino de asesinato y como variante de un posible incendio de la habitación ${ }^{11}$. Méridier pone entre corchetes el grupo de 40-43, siguiendo a Nauck y considerándolo una anticipación de segunda mano; Rodríguez Adrados, en cambio, justifica como auténticos ambos loci: «el curso de los pasajes y la sintaxis de los mismos excluyen la idea de la interpolación" (p. 257). Coincidimos con esta postura, pensando que la función general del prólogo, como apertura de líneas a desarrollar a lo largo de la pieza, justifica el pasaje, como asimismo la ambigüedad de 42-43 favorece la creación de expectativa. Hay que tener en cuenta que la nodriza presenta sus temores, vagos, inciertos, pero posibles dado el carácter de Medea.

A continuación entra el pedagogo, quien anuncia que a la desgracia del abandono se suma ahora la decisión de expulsar a Medea y a sus hijos. La nodriza se indigna contra Jasón y entonces el instructor lanza una reflexión general sobre el egoísmo de la gente: “¿Quién de los mortales no [es malo con sus amigos]? ¿Sólo ahora sabes esto, que toda persona se quiere más a sí misma que al vecino, unos justamente, otros por ventaja, si un padre no ama a éstos a causa de una cama?”. En este pasaje, Brunck condenó el verso 87, "los unos justamente, los otros por ventaja". Méridier lo sigue, si bien reconoce que puede ser defendido y que el escoliasta lo comenta; pero considera superflua la reflexión y advierte que a los tres versos de la nodriza deberían responder tres del pedagogo y no cuatro ${ }^{12}$. Pensamos que la reflexión no es para nada superflua ${ }^{13}$ : la referencia a los que se quieren más a sí mismos que al vecino, pero justamente, alude a Medea; los que lo hacen por propia conveniencia aluden a Jasón; el mejor ejemplo es que éste descuide a sus hijos por una nueva boda. En cuanto al paralelismo en la extensión de versos, si

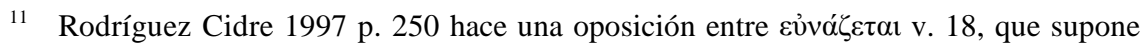

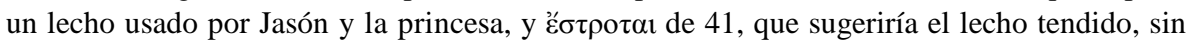
uso, de Medea. En 41, la mención aludiría entonces a que Medea se suicida por el abandono que sufre. Pero en 380, el lecho tendido está en la habitación de la nueva pareja. Podemos pensar que Eurípides reutiliza ahora la misma expresión queriendo aludir a que en realidad la

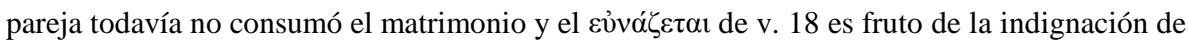
la nodriza, o que Medea prevé que al matarlos el lecho quedará tendido, sin uso. Para Rodríguez Cidre, tanto la idea de é $\sigma \tau \rho \tau \alpha$ r como el singular mortuorio $\lambda \dot{\varepsilon} \chi o \varsigma$ sugieren que

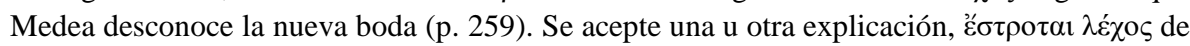
380 no invalida la autenticidad del verso.

12 Méridier p. 126 nota 1.

13 González de Tobia 1983 funda toda una interpretación precisamente a partir de este pasaje. 
fuera tan rígido habría que ver lagunas o añadidos al menos desde el verso 61, pues la relación de versos pronunciados por el pedagogo y la nodriza es: $2 / 1,1 / 2,7 / 2,2 / 2,2 / 3,4 / 7$; es decir, no hay una clara voluntad de equilibrio de extensión. Por lo tanto, no creemos que haya que suprimir el verso: su función sigue siendo la propia de un prólogo, es decir, caracterizar la situación y abrir líneas de interpretación, sugerir advertencias y crear expectativa ${ }^{14}$.

El protagonismo por alusión culmina en 90-95, cuando la nodriza, tras recomendar que se resguarde a los niños, explica que lo aconseja porque la vio

$$
\begin{aligned}
& \text {... hecha un toro en su mirada } \\
& \text { hacia ellos, como si tuviera ganas de hacer algo; y no cesará } \\
& \text { su cólera, lo sé claramente, antes de lanzarse sobre alguien. } \\
& \text { Ojalá tenga ganas de hacer algo contra enemigos, no contra amigos. }
\end{aligned}
$$

Queda así planteada la posibilidad de que los niños sufran una agresión por parte de la ofendida. Inmediatamente comienza el protagonismo de Medea en off, es decir, comienza a oírse su voz desde el interior. Y lo primero que Medea dice en su queja es “¡ay de mí! ¿Cómo podría perecer?” (v. 97), lo cual sugiere que ella orienta su dolor hacia la autodestrucción. La nodriza interpreta esto como la movilización de la cólera y redobla el resguardo de los niños (98-105). Medea exclama entonces:

$$
\begin{aligned}
& \text {... oh malditos } \\
& \text { hijos, ojalá perezcáis por la odiosa madre } \\
& \text { junto con el padre y que la casa toda se vaya a la ruina. (112-114) }
\end{aligned}
$$

Medea, indignada contra Jasón, se arrepiente de todo lo hecho con él y quisiera aniquilar todo lo que se vincula a él, incluidos los hijos, que recuerdan a Medea su error de haberlo amado y la ofensa que él le inflige. Ésta sería la respuesta a las preguntas que se hace luego la nodriza (116-117) acerca de qué tienen que ver los niños con el extravío del padre, por qué ella los odia. La nodriza repite que la gente del nivel de Medea, por ser poderosa, no oye consejos y no cambia su ira (119 ss.) Y aconseja la mesura contra el exceso, advirtiendo que éste puede traer mayores castigos (125-130). Esta idea de destrucción de todo lo que la vincula con el marido traidor le genera un conflicto con su afecto de madre: esto surge no sólo de que Medea se

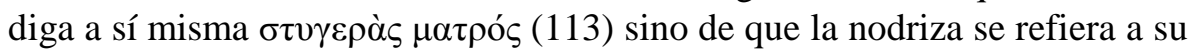
mirada de leona parturienta (187), situación en que las hembras son particularmente defensoras de su cría.

14 Rodríguez Adrados 1993 p. 260 opina que el verso puede ser prosaico e innecesario, pero que no es irrelevante; prefiere seguir los manuscritos y no rechazar lo que parece digno del poeta. 
Entonces se inicia la $\pi \alpha ́ \rho o \delta o \varsigma$, original por su estructura aestrófica con $\dot{\varepsilon} \pi \iota \rho \eta ́$ $\mu \alpha \tau \alpha$ intercalados; este canto coral reelabora los sentimientos del prólogo: dolor, miedo, ansiedad, amenaza, desesperación. En las quejas de Medea reaparece la idea de autodestrucción, con deseo de la propia muerte:

¿Qué ventaja es para mí vivir todavía?

¡Oh, oh! ¡Ojalá con la muerte me disuelva

abandonando esta vida odiosa! (144-147).

Algunos críticos interpretan que Medea le hace creer al coro que quiere suicidarse ${ }^{15}$. Sin embargo, no hay razones para pensar que este depresivo deseo de la propia muerte no sea verdadero: Medea está confundida y sopesa esta posibilidad, así como la misma nodriza la había previsto (40-41), alternándola con su deseo de que se destruya la casa de Jasón. Recordemos que Medea está en el interior de la casa y el coro pide llamarla afuera sólo en v. 184 , de modo que Medea no conoce la presencia de las mujeres ${ }^{16}$ y no puede hablar de suicidio como una mera treta para ganarse su simpatía. El coro entiende esta posibilidad de suicidio ("se apurará el fin de la muerte", v. 154) y por ello tiene valor ambiguo su pregunta " ¿Qué deseo de la terrible

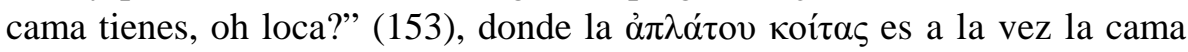
matrimonial perdida y el lecho de muerte deseado ${ }^{17}$. El coro opina que no vale la pena que se consuma por Jasón.

Entonces Medea alterna su anhelo de muerte con el de la muerte de sus enemigos:

¡A él [maldito esposo] y a su novia alguna vez ojalá los vea yo desgarrados con el palacio mismo! (163-164).

Donde aparece una interpretación posible de aquel temor de la nodriza en

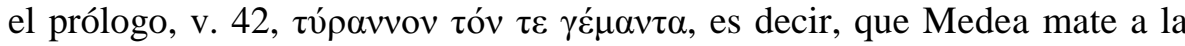
princesa y a Jasón. También el coro teme que el dolor de Medea se vuelque contra los suyos, pues exhorta a la nodriza a que la haga salir "antes de que perjudique en algo a los de adentro" (182-183). La nodriza justifica este te-

15 Por ejemplo, Gambón-Cerra 1991-1992 p. 57 a propósito de vv. 225-227; cf. infra.

16 No nos parece acertada la interpretación del escoliasta acogida por Méridier p. 127 respecto del v. 113, en el que Medea lanzaría una imprecación contra sus hijos porque los ve llegar. Pensamos que Medea está en el interior, no se la ve ni ve ella lo que ocurre en escena.

17 Sobre la imagen del lecho cf. Rodríguez Cidre 1997. El 'lecho' en singular puede tener valor referido a la muerte. "A $\pi \lambda \alpha \tau o \varsigma$ es en principio 'inabordable': Medea no puede acceder al lecho matrimonial y, a la vez, el lecho de muerte debería no ser abordado, de ahí la acepción 'terrible' (cf. Bailly s.v.). 
mor diciendo que la mirada de Medea "se transforma en un toro para las sirvientas, cada vez que alguna se pone cerca aportándole una palabra" (188-189). Los temores, pues, tienen como objeto a cualquiera que se tope con Medea, porque "no hay modo de que con poca cosa mi patrona cese su cólera" (172-173). Ni Medea ni la nodriza ni el coro tienen claro cuál va a ser el proceder; sólo saben que la domina la cólera y que a partir de odiosas penas, "tremendas muertes y fortunas derriban moradas" (197-198), es decir que, dada la situación, pueden prever desgracias.

La queja de Medea se orienta luego contra Jasón, según declara el coro en 204-212, y precisamente entonces Medea sale de la casa, supuestamente para ser calmada por el canto (199-200) y evitar que dañe a alguien

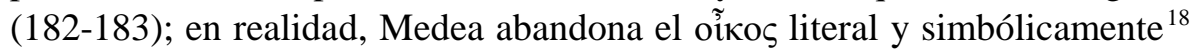
y, más que resignar una venganza, la pone en marcha. Se inicia aquí el protagonismo visible de Medea, que permanece en escena constantemente hasta el v. 1250 .

Medea reconoce que el abandono la arruinó:

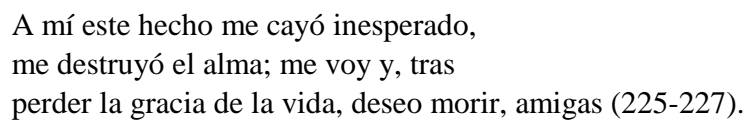

La posición de "amigas", a final de verso, es enfática y se opone a la que

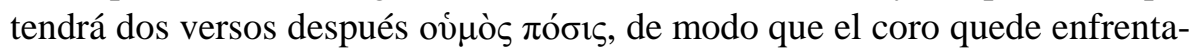
do al marido traidor, a quien Medea se refiere muy diplomáticamente. Es posible que el deseo de la propia muerte acentúe la predisposición benevolente del coro, pero si Medea busca este efecto, eso no quiere decir que, antes de salir del oĩ blecer su $\tau \mu \eta ́$ ultrajada. Entre esa posibilidad y otro modo de vengarse de Jasón, Medea se está inclinando por esto último: de ahí que su última queja, comentada por el coro (204-212), se dirija contra él y de ahí que inicie un discurso sobre las desventajas de la mujer en el matrimonio (230-251) y una descripción de su propia soledad e indefensión (252-258). Entonces Medea expresa claramente su inclinación a castigar al marido:

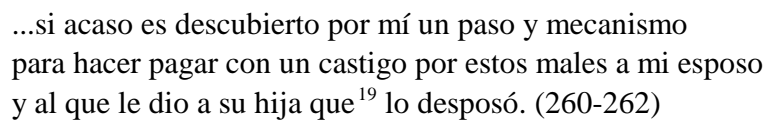

18 Cf. Guelerman 1997.

19 Si se acepta la enmienda de Porson (ฑ̈ en nominativo); de todos modos, la lección de los manuscritos (弚 en acusativo) puede defenderse como atracción de caso o, como hace Ro- 
Todos aceptan el verso 261 donde Jasón es objeto de castigo; en cambio, el verso 262 fue condenado por Lenting como una anticipación de lo que se dirá en 288. Es cierto que en 267, cuando el coro responde, dice que "justamente harás pagar a tu esposo", como desconociendo la alusión al rey, lo cual haría pensar que el verso 262 es espurio. Pero tampoco se menciona aquí a la princesa, a pesar de que en 163 Medea la había mencionado expresamente ( $v v ́ \mu \varphi \alpha v$ ) como objeto de su mal deseo. Es decir, podemos interpretar que Medea sigue con su indecisión, sus dudas, sus vaivenes: siente cólera y quiere vengarse y va pasando su odio de uno a otro destinatario, inclusive a sí misma, porque se acusa de haber traicionado a su familia y su

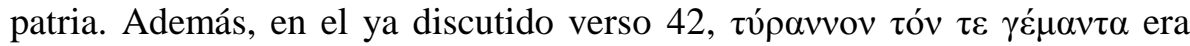
una expresión ambigua que podía entenderse como "a la princesa y al que la desposó" o como "al rey y al que se desposó"; en este último sentido, sería un antecedente de este verso 262. Por otra parte, creemos que la referencia al rey es aquí auténtica, pues sirve además como anticipo de la entrada en escena que él va a hacer ocho versos después. Veremos luego que ocurre algo similar en la entrada de Egeo. Asimismo, se puede pensar que Medea ve el castigo de Jasón y su nueva esposa como un castigo indirecto para el rey y que por eso incluye a éste aquí. En cuanto a la respuesta que da el coro, podemos pensar que, como mujeres que no se ocupan de lo político y legal, no se interesa por el soberano y por eso no lo menciona, o que prefiere concentrar la justicia del castigo en Jasón. Si tenemos en cuenta estas valencias del texto, no es necesario suprimir el verso 262, que Page considera añadido para lograr coherencia con el v. 288. En 287-289 Creonte dice:

Oigo, porque me lo anuncian, que tú amenazas

hacer algo al que la da, al que la desposa y a la desposada.

Según los rumores en los que Creonte se funda, los que corren peligro son él, su hija y Jasón: no hay incoherencia con lo que hemos visto. Al marido se refiere Medea expresamente; túpavvov puede ser entendido como 'princesa' o como 'rey'; y en el castigo de la princesa va implícito un castigo indirecto a su padre. Los tres, pues, estaban ya involucrados, en el contexto previo, como posibles receptores de la venganza, que Medea misma no tiene aún clara, salvo en que Jasón debe ser el eje de su concreción. Lo cierto es que Medea pide al coro que guarde silencio (263) y el coro acepta

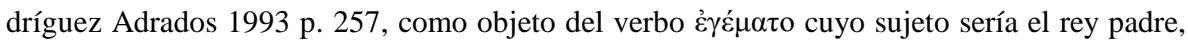
aunque habría cierta tautología: "al que le dio a su hija que entregó en matrimonio". 
$(267)^{20}$, hallando justificada la venganza ${ }^{21}$.

Creonte mismo sabe que el centro del odio de Medea es Jasón: así dice en 271, "tú la de rostro sombrío y animosa contra el esposo"; sin embargo, su temor se refiere a su propia hija como posible víctima de Medea:

no sea que me hagas algún mal irremediable a mi hija (283).

Allí introduce como explicación los vv. 287-289 antes traducidos, que justifican el miedo de que Medea se vengue de Jasón y de él, autores de la nueva boda, en la persona de la novia, beneficiaria de ella.

Medea dice a Creonte que no debe temerle porque

...a mi esposo

lo odio; mas tú, creo, hiciste esto siendo prudente,

y ahora no envidio que lo tuyo esté bien. (310-312)

Posiblemente, contra lo que declara, Medea toma la decisión de dañar a la princesa e, indirectamente, a su padre, precisamente por la actitud que Creonte tiene hacia ella al sentenciar su destierro y al amenazarla con el uso de la violencia (335) ${ }^{22}$. El negar su fama, su sabiduría, su animadversión hacia él, es un recurso para lograr que no la expulse; cuando no da resultado, acude a la súplica $(324,326)$, invoca a Zeus (332) y reduce el petitorio a un solo día destinado a preparar la salida y su sustento (340-347). Creonte comete conscientemente la $\alpha \mu \alpha \rho \tau i ́ \alpha$ de aceptar (348-351) creyendo que unas horas no bastarán a Medea para dañarlo: de ahí que amenace

20 Para Arnott 1984-5 p. 153, el coro acepta expresa y no tácitamente para que se justifique su lealtad pese al horror de la venganza. El coro es leal en no delatar a Medea, pero no acepta su crimen e intenta disuadirla.

21 Un análisis psicopatológico de Medea encuentra que no es loca porque no pierde contacto con la realidad, no delira ni es autista; Medea no puede elaborar el duelo de la decepción respecto del ser idealizado y, en vez de hacer una mentalización, pasa a una desvalorización y actúa; tiene fragilidad narcisista e identitaria pero determinación implacable, impulsividad, inestabilidad afectiva, depresión siniestra entre neurosis y psicosis, todo lo cual es un atenuante. Así analiza al personaje Sztulman 1996 pp. 135-136.

22 Hay pocos usos del término 'violencia'. Medea dice en 242 que es una suerte llevarse bien con el marido, sin violencias ( $\beta i ́ \alpha$ l). Creonte le pregunta por qué se violenta ella negándose a marcharse ( $\beta 1 \alpha ́ \zeta \varepsilon ı$ 339). Y en 1216 Creonte intenta desprenderse de los venenos $\pi \rho \grave{\sigma} \sigma$ Bíav pero eso le produce desgarros de la carne. Puede ser paradójico que un texto como el de Medea tenga tan baja ocurrencia de este vocablo; sin embargo, la violencia surge del asunto mismo, de la traición, del conflicto, de la acción vengativa; violencia espiritual más que física, como opina Ranger 1996 p. 231. Por error, Menu 1996 p. 124 sostiene que no aparece en el texto el término ßía, pero que la violencia se manifiesta en el cumplimiento del ser, en el juego de ser-tener que es su causa. En cuanto a la violencia verbal, cf. Mattiace 1993. 
matarla si permanece más tiempo (354). Los versos 361-362 también fueron condenados como un añadido contradictorio:

y ahora, si es necesario que te quedes, permanece por un día; pues no harás algo tremendo de lo que tengo miedo.

Rodríguez Adrados ${ }^{23}$ los defiende siguiendo a Page p. 99: si bien dio a entender que el amanecer no debe encontrarla allí (352), la concesión se funda en que un día no bastará para hacerle mal. Uno podría preguntarse si no se desprende eso ya de la concesión previa y si no hay una contradicción entre "la llama del dios que está viniendo" (352), o sea, una aurora ya cerca-

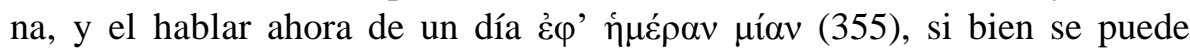
entender esta expresión como una sinécdoque. Resulta extraño que tras decir en 354 "queda dicha esta palabra no mendaz", que parece cerrar el discurso

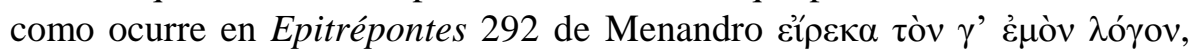
Creonte añada dos versos más. Sin embargo, el rey no cierra con esa frase el discurso: sólo afirma que no es mendaz su amenaza de que la matará. Luego añade por qué hace la concesión.

Dada la circunstancia de disponer ahora de unas horas, Medea retoma su idea de venganza. En 366-7 dice "Todavía hay luchas para los novios recientes y no pequeñas penas para los que hicieron la alianza". Los $\alpha \dot{\gamma} \tilde{v} v \varepsilon \varsigma$ o "luchas" se refieren específicamente a la nueva pareja, Jasón y la princesa; los đóvor "para los que hicieron la alianza" es, de nuevo, un término ambiguo. Méridier p. 137 considera que el plural es mayestático y se refiere sólo a Creonte, pero también puede aludir a Jasón y la princesa en tanto contrayentes o a Jasón, Creonte y su hija en tanto negociantes y partícipe. A la princesa la considera enemiga porque, si bien no es responsable de la negociación normalmente acordada por los hombres, es concretamente la "reemplazante": Medea se ve desplazada como esposa y como patrona del hogar y, para colmo, por una mujer más joven $(445,694,967,970$; cf. 1150). Medea es poco clara en la expresión de su idea, posiblemente porque sabe que el coro la apoya en su venganza contra Jasón (267) pero no está segura de que las mujeres corintias estén acordes en que la venganza alcance a otros. Sin embargo, tras declarar que halagó a Creonte con astucia (368) y que el rey actuó tontamente (371), se atreve a expresar su resolución de castigar a los tres $^{24}$ :

${ }^{23} 1993$ p. 261.

24 Gambón-Cerra p. 59 señalan que el coro es ignorado como interlocutor en 364-409. Quizás el monólogo funcione como un "aparte". 
... a tres de mis enemigos haré

cadáveres, al padre y a la muchacha y a mi esposo (374-375).

Aquí Medea toma una primera decisión; sin embargo, sabemos que en el curso de los acontecimientos la cambiará, pues no hará de Jasón un cadáver o, al menos, no en sentido literal. Además, tampoco decidió el método. A partir del v. 376 discurre si usará el fuego, la espada o las hierbas, y opta por éstas para evitar ser atrapada en el palacio. A tal punto está decidida que en 386 dice $\kappa \alpha \grave{~} \delta \varepsilon \grave{\varepsilon} \tau \varepsilon \theta v \tilde{\alpha} \sigma$, "ya están muertos", como hecho consumado. Pero luego discurre una opción de máxima y una de mínima: si encuentra un refugio, asilo o protección, actuará con dolo y en silencio (de hecho prevé que quizás aparezca alguna ayuda, 389-391); si no lo consigue, los matará a espada aunque ella muera a consecuencia de ello (392-394). Que en su castigo quiere llegar incluso al rey queda confirmado por los versos 399-400:

Yo les haré amargas y lúgubres las bodas, amarga la alianza y mis exilios del suelo

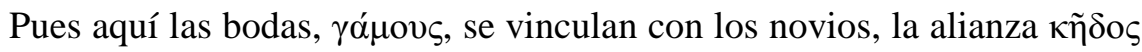
incluye al padre que la concede y los exilios pvyás son responsabilidad directa de Creonte.

Hasta aquí, pues, Medea decidió matar a Jasón, Creonte y la princesa, y decidió hacerlo con venenos o con espada. Veremos cómo "Medea, planeando y tramando artificios" (402), actividad propia de su nombre, irá modificando gradualmente el proceso de la venganza.

El estásimo de 410-445 confirma la capacidad de Medea para vengarse y la justicia de su causa. El ảyõv que le sigue, 446-626 ${ }^{25}$, fija la posición psicológica de los contendientes y permite, por la hipocresía de Jasón, que Medea confirme su venganza, cosa que expresa ambiguamente en 608 ("También para tu casa soy funesta") y 626 ("desposarás de tal modo que reniegues tú de la boda"). En este pasaje se discute la autenticidad del verso 468, que fue condenado por Brunck: a la frase "viniste hasta nosotros, viniste como enemigo", tal verso añade "contra los dioses y contra mí y contra toda la raza de los hombres". Rodríguez Adrados p. 259 opina que debe ser suprimido porque es redundante en boca de Medea, mientras que es lógico que Jasón se lo diga a Medea al final. Es posible, sin embargo, verlo como un modo que tiene Eurípides de variarse a sí mismo y de mostrar que una idea

25 Sobre el uso de la retórica en este pasaje cf. Schamun 2001. 
puede tener distintos puntos de vista y distintas aplicaciones. Para Medea, la traición de Jasón es hostil no sólo para ella sino también para los dioses, por haber violado pactos refrendados por ellos, y para toda la raza humana porque desestabiliza la sociedad, su confianza en los acuerdos y su relación con la $\theta \varepsilon ́ \mu ı c$. En el caso de Jasón, Medea es hostil a él por el castigo que le inflige, a los dioses por osar matar a consanguíneos (las Erinias actuarán) y a la raza humana por violar el vínculo natural madre-hijos y destruir la institución familiar, aunque por supuesto, también Jasón descuidó el vínculo padre-hijos y destruyó la familia que había construido. En fin, no es indispensable suprimir el verso 468, teniendo en cuenta además que Medea está argumentando su defensa y justificando, sin que Jasón lo sepa, la venganza que desea.

Antes de avanzar es importante detenerse en los versos 596-599. Jasón alega que él actuó

$$
\begin{aligned}
& \text {...queriendo salvarte } \\
& \text { a ti y, de la misma simiente, engendrar para mis hijos } \\
& \text { hijos soberanos, defensa de la casa }
\end{aligned}
$$

Lo cual genera un comentario de Medea que dice:

$$
\begin{aligned}
& \text { Ojalá no se me haga triste una vida feliz } \\
& \text { ni una opulencia que hace escocer mi sentir. }
\end{aligned}
$$

Con un tono irónico, Medea sugiere que no quiere esa vida que Jasón propone para sus hijos, pero también puede dar lugar a pensar que tuvo una ocurrencia: si a Jasón le interesan los hijos, sería un castigo que ya no los tuviera; este podría ser el sentido del deseo de Medea de que su vida feliz (tener a sus hijos) no se le haga triste (tener que matarlos). Que se le ocurrió esta idea quedaría confirmado por las alusiones de los versos 608 y 626 ya citados: ser funesta para la casa de Jasón es ser destructora de los niños; que Jasón reniegue de su boda es que tome conciencia de que le valió quedarse sin hijos.

De tal modo, Medea añade ahora en su plan gradual de venganza la idea del filicidio, con el cual no hará cadáver a Jasón literalmente sino simbólicamente, porque lo deja sin futuro.

En el segundo estásimo, 627-662, el coro opone el exceso de los ह́po $\varepsilon \varsigma$ a la mesura de Kv́ $\pi \rho ı \varsigma$, que puede entenderse como una condena de la infidelidad pasional, carente de $\sigma \omega \varphi \rho \sigma^{\prime} v \dot{v}$. Es importante su sentencia final, cuando dice "ojalá muera el ingrato a quien le es posible no honrar a los amigos, abriendo la llave de puros sentimientos; para mí nunca será un amigo" (656-662): la maldición se dirige contra Jasón pero a la vez anuncia la figura 
de Egeo que aparecerá inmediatamente. El que debía ser agradecido y amigo no lo es (cf. 696, 698); en cambio, quien no tiene obligación alguna, lo es.

Y así se presenta Egeo sólo dos versos adelante y en posición destacada: фí̉ous:

Medea, salud. Pues proemio más bello que éste nadie sabe dirigir a amigos. (663-664)

Egeo había sido, si no previsto ${ }^{26}$, al menos esperado como una posible salvación cuando Medea evaluaba las posibilidades de los métodos de venganza. Además, aparece de modo similar a como en Edipo, rey aparece el mensajero, inmediatamente después de que Yocasta afirma la invalidez de los oráculos. Aquí, el coro lamenta la deslealtad e ingratitud de supuestos amigos y tiene como respuesta la venida de un amigo leal ${ }^{27}$.

La escena de Egeo, mal vista ya por Aristóteles ${ }^{28}$ y por muchos críticos modernos, es ahora revalorizada ${ }^{29}$. Ciertamente tiene posición central, no sólo desde la estructura externa sino también desde la interna. Egeo busca hijos, en oposición a Medea que matará a los suyos y a Jasón que, en busca de otros que son excusa para su propio beneficio, se desentiende de los que tiene; Egeo está casado, aparentemente sin problemas conyugales, a diferencia de Medea y Jasón, pero carece de hijos (no sabe que al visitar a Piteo engendrará extramatrimonialmente uno en Etra, hija de Piteo) ${ }^{30}$. La figura de Egeo sirve para la venganza de Medea en dos aspectos: por una parte, le hace ver cuán importante es para un hombre su descendencia, de modo que aquella idea naciente de vengarse de Jasón en sus hijos se muestra confirmada ahora para Medea como la más cruelmente efectiva; por otra parte, la benevolencia y el juramento de Egeo le aseguran a Medea un refugio o asilo, la protección que ella necesitaba para actuar según la opción de máxima, es

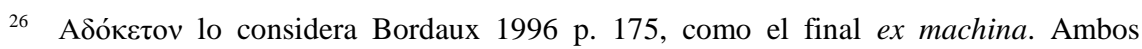
pasajes, sin embargo, tienen algún anuncio (para el carro, no sólo la insistencia en Helio como ancestro de Medea sino también el v. 1297; cf. Collinge 1962).

27 Quien menos conoce a Medea, más compasión y amistad le tiene: cf. Jouan 1996, pp. 87 y 96. Sin embargo, Medea no lo trata honestamente, pues Egeo no sabe qué piensa hacer ella; de ahí que el coro, en el tercer estásimo, distinga entre ella y otros refugiados en Atenas.

28 Cf. Poética 1461 b 20; Aristóteles la considera ón habría "mejorado" esta escena en su versión. Cf. Melero 1996 p. 65.

29 Para Menu 1996, por ejemplo, la escena redinamiza a Medea en todo su ser y es un espejo de la súplica a Creonte (p. 113). Egeo sirve como "principio de reversión del no-ser de Medea” (p.119).

30 Sobre las cuestiones matrimoniales en Eurípides cf. Seaford 1990. 
decir, con dolo, secretamente, mediante venenos y sin exponerse a ser muerta en palacio. Además, desde el punto de vista mitológico, la aparición de Egeo alude y prepara su vínculo futuro con Medea y el nacimiento de Medo, aludido también en v. 1385, lo cual acentúa la contraposición con Jasón, que queda sin posibilidad de herederos.

En este pasaje se discute la pertinencia de los versos 725-726, bien defendidos por Page y Rodríguez Adrados: la insistencia del personaje no es razón para suprimirlos; Egeo añade que acepta recibirla pero no llevarla él mismo, pues hacer esto significaría un agravio a la tierra que él ahora visita. Los versos 729-730 son la explicación del 726, es decir, de por qué él se niega a llevarla. Habría que añadir como argumento que esta advertencia prepara el final de la pieza: Medea consigue un refugio contra su castigo pero no un salvoconducto para llegar a él; debe salir de Corinto por sus medios. ¿Cómo escapar sin ser atrapada por Jasón o por los guardias de palacio? Sólo podrá escapar en el carro de Helio.

Por lo tanto, no sólo la escena es fundamental para la trama de la concreción de la venganza sino que además prepara y justifica el final ex machina.

A continuación, mediante la repetición anafórica de vvv en 765 y 767 , Medea expresa que llegó el кaıpós, la ocasión adecuada ${ }^{31}$ : obtenido el refugio, puede iniciar la venganza. Cumplidos los requisitos, puede revelar el plan. Entonces anticipa que engañará a Jasón, que enviará a sus hijos con regalos para la princesa con los cuales, envenenados, matará a ésta. Aquí expone, pues, abiertamente su intención de matar a la princesa, con lo cual piensa castigar indirectamente también a su padre; sin embargo, queda anunciada y abierta la posibilidad de que también él muera, porque Medea dice (788) "morirá malamente todo el que toque a la muchacha". Asimismo anuncia, cambiando el tono y el ánimo (790-791), que decidió matar a sus hijos (792) para destruir la casa de Jasón (794), quien no podrá tampoco tenerlos de su nueva esposa (804-806). Medea lo anuncia con dolor y con plena conciencia tanto de la impiedad del crimen como del sufrimiento que le acarreará (796). Este aspecto de la venganza fue el último en ser incluido en el plan y como variante de la muerte de Jasón. Lo justifica con tres razones: 1) que tras matar a la princesa no tendrán provecho en vivir ni tiene ella nada que ofrecerles (798-799); 2) que de tal modo Jasón pagará su culpa, la cual queda sugerentemente enlazada con la propia culpa de Medea ("me

31 Cf. Guelerman 1997 p. 122. 
equivoqué otrora cuando abandoné la morada paterna”, 800-801); 3) que así ella es fiel a su carácter, "pesarosa para los enemigos y benévola para los amigos" (809). Quizás tomando la implícita contradicción de esta razón (los hijos son amigos y, sin embargo, los matará cruelmente), el coro intenta vanamente disuadirla y pasa luego a cantar, en el tercer estásimo ${ }^{32}$, la oposición entre un amor constructivo y un furor destructivo.

En la escena que acabamos de comentar se discute la autenticidad del verso 782, suprimido por Brunck en razón de que se repite en 1061. El pasaje dice:

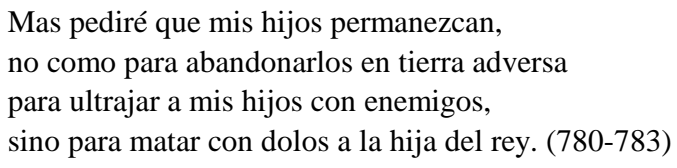

Medea explica que logrará de Jasón que sus hijos no sean exiliados, pero no porque piense dejárselos sino porque los usará para matar a la princesa. La idea de que si se quedan en Corinto serán ultrajados por los enemigos es coherente con su previo temor de ser atrapada ella misma (381-383) y con la versión mítica de haber sido ellos muertos por los corintios. Hay que observar que el verso 1061 no es formalmente igual al 782 sino que tiene la misma idea, como no lo será el verso 1380 a pesar de reiterarla y menos aún 1238-1239: tiene razón Rodríguez Adrados al defender la autenticidad del verso alegando que obsesiona a Medea la idea de que sus hijos queden a merced de los enemigos ${ }^{33}$.

También son cuestionados, de este pasaje, los versos 785-786. El primero es considerado interpolación por Valckenaer y el segundo es suprimido por Elmsley; se fundan en una semejanza formal con los versos 949-950, aunque en realidad son iguales solamente 786 y 949. El pasaje dice, refiriéndose a los niños:

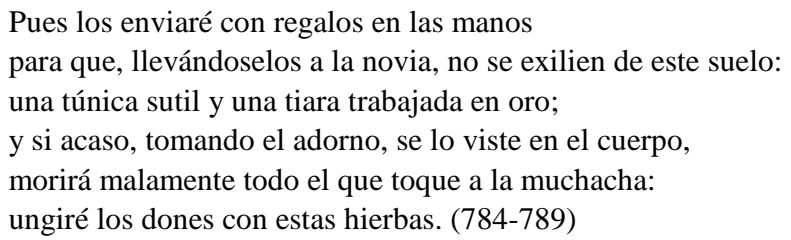

\footnotetext{
32 Sobre éste, cf. Most 1999, a cuya plausible propuesta para la interpretación de los vv. 856-859 añadimos como argumento en defensa de è (856) la trasposición poética de te en

33 Rodríguez Adrados 1993 p. 258.
} 752. 
Rodríguez Adrados ${ }^{34}$ defiende el pasaje alegando su sintaxis perfecta y que, si se suprime lo cuestionado, el locus queda débil. Que Medea insista cuando habla con Jasón no es un obstáculo. Ciertamente, el verso 785 no puede faltar porque se refiere al favor que se pretender obtener; el 786 explica cuáles son los regalos mencionados en 784 y 789, aclaración necesaria para entender por qué la princesa puede ponerse un adorno en el cuerpo, que terminará dañándola a ella y a quien la toque. El regalo podría haber sido algo más externo o independiente del cuerpo de la destinataria, mientras que el relato que hará el mensajero explana por qué los dones debían ser algo que la princesa pudiese ponerse encima (cf. 1159 ss., 1186 ss.). Por otra parte, que al hablar con Jasón Medea le explique, en 949, que los dones son una túnica y una diadema de oro no es algo fuera de lugar, sobre todo teniendo en cuenta que, después, Medea explica que la tiara es un adorno legado por Helio a su descendencia, y observando también que el mismo Jasón mencionará los dones como túnicas y oro (960-961); si bien éste puede ya verlos porque una sirvienta los aportó (cf. 951 y 956), no es un exceso que Medea los haya mencionado ni es reiterativo respecto de 786 porque en esa ocasión Jasón no estaba presente. Además, estos objetos cumplen un papel tan importante en el desarrollo de la venganza que no es dramáticamente inadecuado insistir en ellos. Tengamos presente que también los versos 1163 y 1190

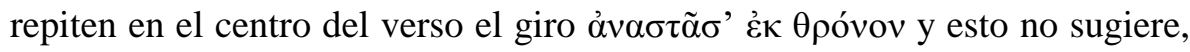
sin embargo, que alguno de ellos sea espurio.

En el cuarto episodio (866-975), Medea pone en marcha la concreción de la venganza mediante su engañosa actuación ante el marido y el envío de los objetos envenenados, cuando Jasón incurre en $\alpha \mu \alpha \rho \tau i ́ \alpha$ (908 ss.). Medea, empero, sigue con ciertas dudas: llora y teme al ver cómo los niños estrechan la mano de su padre (899-903), llora porque planea matarlos y teme por el dolor que padecerá al hacerlo, a la vez que el ademán le recuerda el pacto violado por Jasón, lo cual acentúa el conflicto; también llora y torna el rostro cuando Jasón ruega que sus hijos lleguen sanos a la juventud (920-924), porque este deseo, que sería también el suyo, redobla el conflicto contra su decisión criminal. En este sector se cuestionan los versos 923-924 alegando semejanza con 1006-1007:

Tú, ¿por qué tiñes con frescas lágrimas tus pupilas, tornando a otro lado la blanca mejilla, y no acoges contenta este discurso de mi parte? (922-924)

\footnotetext{
34 Ibidem.
} 
Nuevamente, solo son iguales 924 y 1007, mientras que los previos son parecidos ${ }^{35}$. Rodríguez Adrados acepta que se supriman 1006-1007, considerando allí rápida y directa la pregunta del mensajero. Pensamos que en ambos pasajes son necesarios estos versos. Para el público, el único indicio de

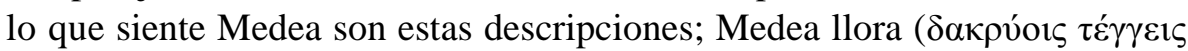
922) y está confundida ( $\sigma 0 v \xi v \theta \varepsilon i ̃ \sigma \alpha 1005)$, pero la máscara no permite observarlo; que se torne el rostro para ocultar el llanto no es extraño (recordemos a Odiseo, que se cubre al oír el relato de Demódoco); en ambos pasajes se acaba de hablar de los hijos, causa del conflicto de Medea, lo cual le produce consternación, una perturbación emotiva expresada con lenguaje corporal. Además, como ya señalamos, en 1163 y 1190 se reitera una escena (el levantarse del trono), como también en 1148 y 1152 se repite y comenta respectivamente la actitud de tornar el rostro, esta vez en la persona de la princesa, alterada por la presencia de los niños ante ella, y el verso $1148^{36}$ es muy parecido al 923, sin que, por lo que sabemos, nadie lo cuestione. Eurípides gusta de recrearse y de hacer guiños a las escenas repetidas de Homero.

En el canto coral de 976-1001, las mujeres prevén la muerte de los niños y de la princesa y asimismo la miseria de Jasón y de Medea. El coro no hace referencia a la muerte de Creonte porque no está planeada ni anunciada como segura: Medea piensa en un castigo indirecto para el rey (el quedarse sin descendencia) o quizás, en su muerte, en caso de que toque a su hija. También Jasón podría hacerlo y morir con ellos. Es una posibilidad incierta que el coro no prevé ni afirma.

El quinto episodio (1002-1080) es el famoso monólogo de Medea tras el anuncio de la marcha inminente de sus hijos con el ayo, en el que el personaje expresa el conflicto preparado antes por su llanto y consternación, pasaje muy discutido por la crítica ${ }^{37}$ : algunos propusieron suprimir 1056-1080; otros limitan la seclusión a $1073-1074^{38}$ o a $1062-1063^{39}$. Kvicala suprimió el verso 1045, cuyo contexto dice:

351006 dice “¿Por qué tornas de lado la mejilla?”

36 1148: "Y tornó a un lado la blanca mejilla".

37 Para Snell 1965 p. 182, este monólogo es central no sólo porque en él Medea decide matar a sus hijos sino también porque en él se subsumen todos los motivos destacados por el poeta. Lejos está, pues, de suprimirlo.

38 Reeve 1972; incomprensiblemente para Rodríguez Adrados 1993 p. 262, pues Reeve defiende el pasaje.

39 Rodríguez Adrados 1993 pp. 258-259, por ejemplo. 
No podría. Adiós a mis determinaciones

de antes: conduciré a mis hijos fuera de esta tierra.

¿Por qué es necesario que yo, afligiendo a su padre con

males de éstos, adquiera dos veces tantos males? (1044-1047)

Medea se cuestiona por qué debe tener doble daño, ser asesina y verse privada de sus hijos. Se plantea la posibilidad de irse con sus hijos al exilio, aunque antes pensó que no tenía nada que ofrecerles allí (798-799). Si Medea no aclara que se los llevará, es incoherente con su declaración de no querer dejar a sus hijos en manos de sus enemigos para que los ultrajen o maten (782, que reaparece en $1061,1238-1239$ y 1380): si decide no matarlos, debe llevárselos consigo. El verso es necesario.

Luego vuelve a opinar que debe matarlos (1049-1055), considerando el

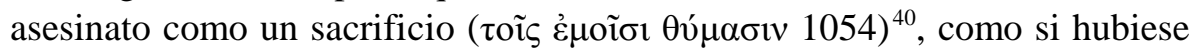
que "aplacar" a los dioses por los pactos violados (cf. 1013); y enseguida

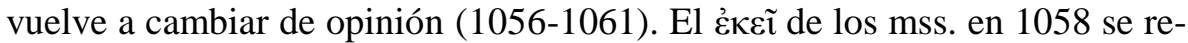
fiere a Corinto y no necesita ser enmendado, porque en esta nueva posibilidad que Medea evalúa, el no matar a los niños implica dejarlos en la ciudad $^{41}$; pero inmediatamante rechaza esta idea, coherente consigo misma, porque eso significaría que los corintios los maltrataran o mataran. En su conflicto afectivo, Medea tiene en cuenta razones ${ }^{42}$.

$40 \quad$ Cf. Boedeker 1997 p. 136.

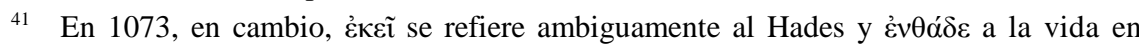

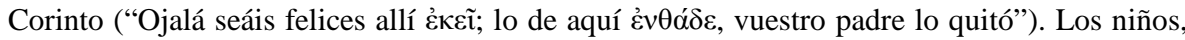

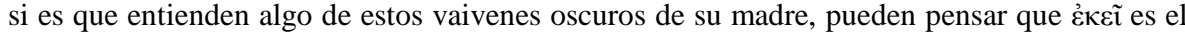
lugar de exilio.

42 Romilly 1973 p. 131 señaló que, mientras que en Homero la duda es clara e intelectual, en Eurípides es pasional, dividida del alma: Medea duda por la ternura que siente por sus hijos. Es cierto que el afecto hace dudar a Medea, pero para resolver el conflicto "argumenta razones" que tienen base afectiva (no dejarse burlar, no librar a los hijos a los enemigos). Habría que rever si, cuando Aquileo desiste de matar pasionalmente a Agamenón por su afrenta, no "argumenta razones" que son también de base afectiva: lograr una mayor timé. Recordemos que los principios que mueven a Medea coinciden con los de los héroes iliádicos. Para Romilly sólo son heroicos en Eurípides personajes como Alceste, Macaria, Polixena y Meneceo, jóvenes que se sacrifican por un ideal (cf. p. 138); para Reinhardt 1972 p. 306, estos jóvenes carecen de la base de sustento que tenían los héroes.

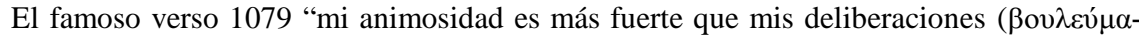
$\tau \alpha)$ " hace referencia a todas estas disquisiciones. Segal 1996 p. 24 plantea la interpretación de $\beta o v \lambda \varepsilon v ́ \mu \alpha \tau \alpha$ 'planes' como una contradicción, un conflicto interno contra el proyecto de ase-

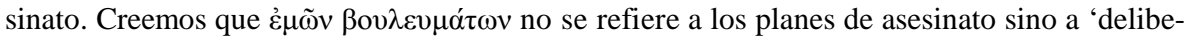
raciones, argumentaciones' en contra de esos planes, enfrentadas al impulso de venganza, a 
Torna entonces a opinar que debe matarlos (1062 ss.). En este pasaje se cuestiona los versos 1062-1063, alegando que son una interpolación tomada de 1240-1241, versos exactamente iguales a aquellos. Que en este segundo lugar Medea diga

Realmente es necesario que ellos mueran. Dado que es necesario, los mataremos nosotros, quienes los engendramos

No está de más, pues en el monólogo de 1019 ss., aunque esté presente el coro, Medea ignora su presencia: habla consigo misma y con sus hijos; en 1240-1241, en cambio, expresa abiertamente al coro su decisión ${ }^{43}$. Pero también son necesarios 1062-1063, de lo contrario, no tiene sentido $\tau \alpha \tilde{\tau} \tau \alpha$ de 1064:

Realmente esto está hecho y no será rehuido

Donde el pronombre demostrativo se refiere a lo que acaba de decir (que los niños morirán y los matará ella) y no a que no se los dejará a los enemigos (1060-1061). El uso del perfecto $\pi \dot{\varepsilon} \pi \rho \alpha \kappa \tau \alpha \iota$ en 1064 señala decisión tomada como cosa hecha, así como dijo $\tau \varepsilon \theta v \alpha \tilde{\sigma} \sigma$ en 386 con el

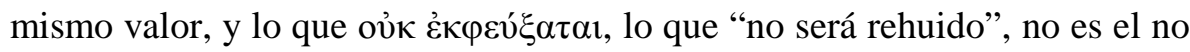
dejar a los niños sino el matarlos. Se alega en contra de la autenticidad la reiteración anafórica de $\pi \alpha$ óvtos en 1062 y 1064; pero también la hay en

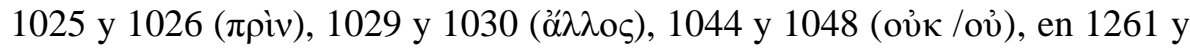
1262 ( $\mu \alpha \dot{\tau} \tau \alpha v)$. No parece válido el argumento.

Creemos que estos versos 1062-1063 son fundamentales. Ellos transmiten la decisión definitiva de matar a los niños, decisión interior tomada tras largo conflicto y que le permite ya superar la duda afectiva (1071-1077); Medea comunica esa decisión a sus "aliadas" en 1240-124144.

En el interludio coral de 1081-1115, las mujeres corintias comentan los

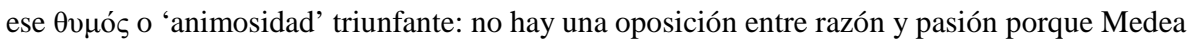
usa, a lo largo de la pieza, la razón para facilitar la venganza, por ejemplo en la búsqueda de la simpatía del coro, en el forzar a Egeo a una alianza juramentada, en la escena del engaño a Jasón; sino que hay un sometimiento de la razón a la pasión. El conflicto por el que Medea delibera ( $\beta o v \lambda \varepsilon v ́ \mu \alpha \tau \alpha)$ es entre el triunfo de la pasión vengativa o el triunfo del afecto maternal.

43 Rodríguez Adrados 1993 pp. 258-259 los defiende alegando una "sutil gradación" entre ambos pasajes: en el primero Medea sólo aludiría a la muerte y hablaría de despedida; en el segundo sería más explícita respecto de la acción que cometerá. No vemos tal matiz.

44 González de Tobia 1983 p. 110 destaca que el discurso de Medea no es "un artilugio psicológico sino un continuum dramático": hasta allí, el personaje había sido incapaz de hacer una decisión interna. 
dolores que suelen causar los hijos, pero que el máximo dolor para un padre es su muerte. Esto se aplicará tanto a Medea como a Jasón y a Creonte: los tres son castigados en sus hijos.

El sexto episodio (1116-1250) es el relato del mensajero. Aquí se cuestiona el verso 1121, en boca del mensajero:

¡Oh tú que has obrado contra la ley tremenda obra...!

Sólo falta en algunos testimonios pero no parece espurio. Es un buen comienzo para el relato que debe hacer el mensajero: la cosa está hecha, de ahí el participio perfecto sip $\gamma \alpha \sigma \mu \varepsilon ́ v \eta$. La venganza, construida gradualmente, se ve concretada en los hechos. El mensajero anuncia que también Creonte murió (1126) y Medea pide que describa

... cómo perecieron, pues dos veces tanto nos encantarías, si han muerto totalmente mal. (1134-5)

El Sís 'dos veces' alude al doble placer de que hayan muerto los dos, hecho que no era seguro aunque posible, y a que además de saberlo lo oiga relatar. Creonte desea morir junto a su hija (1210) pero intenta desesperadamente desasirse del cadáver (1212-1217) hasta ceder y entregarse a la muerte (1218-1219). El mensajero condena el crimen con una frase ambigua ("pues tú misma conocerás la vuelta inversa del castigo", 1223) que puede entenderse como "reconocer que es un castigo para Jasón y Creonte" pero también "reconocer que es y/o habrá un castigo para ella". Y luego emite una sentencia general sobre que "los que parecen sabios y preocupados por los razonamientos, estos son condenados al mayor castigo" (1226-1227). El coro lo aplica a Jasón (1231-2) pero podría aplicarse a Creonte e incluso a Medea misma, sobre todo si tenemos en cuenta la condena previa, velada (1222-1223), la relación $\mu \dot{\varepsilon} \nu \ldots \delta$. asimismo el hecho de que Medea es considerada "sabia" a lo largo de toda la pieza y es muy hábil en sus razonamientos, incluso en aquellos por los que decide matar a sus hijos ${ }^{45}$.

En este episodio se cuestionan los versos 1220 (West) y 1221 (Reeve, Diggle):

yacen muertos la niña y también el viejo padre, cerca, circunstancia propicia para las lágrimas.

Rodríguez Adrados ${ }^{46}$ los defiende justamente, alegando que en este tipo

45 Sobre la sabiduría y habilidad de Medea, cf. López Férez 1996; también Moreau 1996.

46 1993, p. 263. 
de escenas es habitual que se haga mención del cadáver y que se mencione como digna de llanto la muerte acaecida. Podemos añadir que es una culminación muy apropiada para el fin del relato, pues a continuación, el mensajero pasa a la condena del hecho. Para Medea, es coronación del primer estadio de su venganza, pero circunstancia de gozo, no de llanto.

Wilamowitz censuró los versos 1233-1235, en boca del coro:

Oh desdichada, cómo lamentamos tus desgracias, muchacha de Creonte, que hacia las puertas de Hades marchas a causa de las bodas de Jasón.

Para Rodríguez Adrados ${ }^{47}$ es subjetivismo de Wilamowitz el considerarlos un añadido de "actor sentimental" que no quiso ser duro con la princesa. Recordemos que en 267 el coro también elude referirse al rey Creonte como merecedor de castigo y se concentra en Jasón, el mayor culpable; aquí se concentra en la princesa, la mayor víctima en tanto que ella no fue responsable de la alianza hecha por su padre y su marido. Sin embargo, la desdicha del padre queda aludida al referirse a la joven no por su nombre ni por su rango sino como "muchacha de Creonte".

A continuación, Medea expone abiertamente al coro su decisión de matar por propia mano a sus hijos y también expresa, como típico personaje trágico, su clara conciencia de desgracia ineludible para ella.

En el quinto estásimo ${ }^{48}$ (1251-1292), el coro pide a la Tierra, al Sol, a la luz, que detengan a Medea; prevé la Erinia (cf. 1371, 1389), ve el crimen como un castigo por la muerte de Apsirto (1268-1270) ${ }^{49}$, da el ejemplo mitológico de Ino y considera el lecho fuente de males. En medio, se produce el asesinato. Aquí Medea tiene un protagonismo aludido: está fuera de escena y tampoco se la oye, pero las voces de los niños se refieren a las acciones de Medea y el callar de ellos se torna tácita prueba de la perpetración del crimen: la antinaturalidad del filicidio parece reflejarse hasta en la forma lírica, que se hace irregular ${ }^{50}$. El coro llama a Medea "asesina" póvoৎ (1267). $\mathrm{Su}$ inicial apoyo fue gradualmente transformándose en posición adversa.

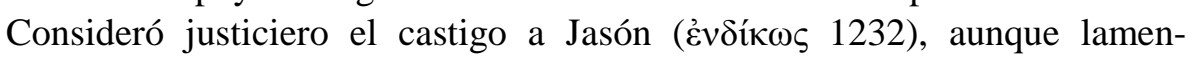

47 Ibidem.

48 Sobre éste, cf. Segal 1997.

49 Acerca de la ruptura que su muerte significa para Medea cf. Bremmer 1997.

50 No sólo cambia trímetros por yambo-docmios sino también suprime el esquema amebeo. Sobre este estásimo véase específicamente Segal 1997. En cuanto a las innovaciones de Eurípides cf. Arnott 1973. 
tándose de la princesa, pero no acepta el asesinato de los niños: si no pudieron detener ellas, las mujeres corintias, a Medea, intentan que la detengan las divinidades; proponen intervenir y salvar a los niños (1275-1276) pero no lo concretan, quizás porque las puertas están cerradas $(1314,1317)$, en parte porque Eurípides reelabora la actitud del coro en el Agamenón de Ésquilo, en ocasión del asesinato del rey ${ }^{51}$. La adhesión del coro a Medea ( $\pi \rho o ́ \theta v \mu$ ov 179) tiene un proceso inverso a la construcción de la venganza: a medida que ésta crece y se hace explícita y más horrorosa, el coro va perdiendo su simpatía por ella ${ }^{52}$; acepta que es injusto lo que le ocurre y que Jasón merece un castigo, pero ve la marcha creciente de la venganza como un exceso que se hace consecuencia de anteriores excesos y que se torna castigo para la misma Medea ${ }^{53}$. Es extraño que algunos críticos consideren que la adhesión del coro se acrecienta a medida que transcurre la obra ${ }^{54}$.

En el episodio final (1293-1414), iniciado con versos que denotan la perturbación emocional de Jasón mediante el desorden sintáctico, se anuncia la

51 Cf. Arnott 1984-5 pp. 148-149.

52 Cf. por ejemplo Gambón-Cerra 1991-2 p. 60, para quienes en v. 811 el coro "comienza a retirarle su alianza". Jouan 1996 pp. 94-95 sostiene que el coro, mudo durante el monólogo de Medea, sale de su pasividad para criticarla como asesina en 1253-4: "El coro se deslizó de la simpatía a la reprobación, luego al horror”. Segal 1996 pp. 19-20 sostiene que la simpatía del coro llega al horror por cuatro razones: la muerte de la princesa, el uso de los niños como instrumento, la preparación del escape y la identificación de los niños con su propio honor. Most 1999 p. 20 destaca el horror del coro y su insistencia en que la intención de Medea es una osadía $(816,859)$ : el coro se va distanciando gradualmente de Medea hasta el final.

También el público pudo ir perdiendo simpatía por ella: se dice que la derrota de la pieza se debió a un rechazo general, vinculado con la impopularidad de Eurípides. Respecto de esta supuesta impopularidad cf. Stevens 1956 y Nancy 1984. Según Stevens no hubo tal, al menos no completa ni general. Quizás sea comparable al caso de nuestro J. L. Borges, elogiado por muchos por su obra pero un tanto impopular entre otros por sus actitudes e ideas.

53 La crítica suele considerar que Medea no es castigada por su crimen debido al final "triunfante" y que esta falta de harmonía universal es el comienzo de la tragedia moderna, donde reinan fuerzas inconciliables (cf. por ej. Citti 1996). En realidad, Medea se autocastiga con su propio sufrimiento y es consciente de ello $(1250,1397)$ : pero no puede rehuir el crimen y eso la hace personaje trágico.

54 Para Rodríguez Cidre 1997 p. 267 el coro se abstiene de condenar a Medea en el momento del filicidio, porque se compadece de ella, y usa entonces el lecho como interlocutor. Recordemos que Medea entra a la casa (1250) por lo que el coro no puede hablarle; si bien la considera "desdichada, malafortunada" (1272) como a Ino (1286), quiere detenerla (851 ss., 1251 ss.), no la exime de su culpa y no deja de sentir horror por su crimen: "¿Qué cosa, en efecto, podría ser aún más tremenda?" (1290). 
salida ex machina como un salvataje que Jasón cree ảov́vatov (1296-1298). El pasaje se centra en el tema del castigo. Jasón quiere evitar el de los niños, que podrían sufrir la cólera de los parientes de Creonte (1301-1305); no le importa que se venguen de Medea (1299-1301) sino que él mismo quiere castigarla (1316) al enterarse de que cometió el filicidio. Jasón creía que las mujeres le advertían sobre la posibilidad de que Medea lo matara a él (1308), pero comprende que con la muerte de sus hijos también lo mató a él, no físicamente pero sí en sus intereses: la posteridad y el beneficio material $(1310,1325)$. De tal modo, el que quería evitar un castigo y aplicar otro, no hace ni una ni otra cosa y resulta castigado (1306, 1310, 1325, 1347-1350, 1395). En este pasaje se cuestiona el verso 1316:

Soltad las trabas cuanto antes, sirvientes, liberad las juntas para que vea el doble mal,

a los muertos por una parte, a la que haré pagar su culpa, por otra. (1314-1316)

Schenkl lo suprimió alegando oscuridad de la frase; Rodríguez Adrados ${ }^{55}$ lo defiende justificando por la pasión del personaje la falta de lógica, es

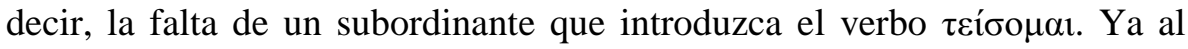
comienzo del episodio Jasón mostró perturbación en su modo de expresarse, de modo que puede darse también aquí.

Medea, por su parte, que es ahora protagonista apoteótica, triunfante y salvada divinamente ${ }^{56}$, expresa con claridad a quiénes consideró enemigos y de quiénes quiso vengarse:

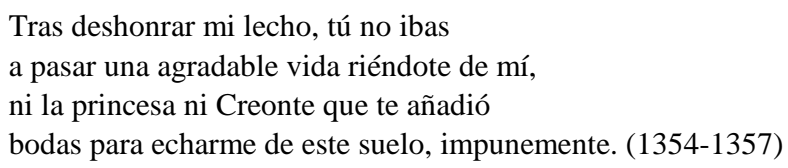

Medea sintetiza todo: se la deshonró como mujer-madre, este ultraje es una burla para ella, lo cual motiva su venganza contra los implicados, el marido, la novia y el suegro, venganza que consiste en punirlos. Frente al logro de su venganza, no le importa que Jasón la llame cosa odiable y enemiga (1323), traidora (1332), leona $(1342,1407)$ o Escila (1343): logró que no puedan burlarse de ella (1362) y que él quede cruelmente castigado (1370, 1398); mientras que sus hijos tendrán ceremonias que compensen la

$55 \quad 1993$ p. 263.

56 Observa Bordaux 1996 p. 173 que al quedar Medea fuera de la ciudad, sin esposo ni hijos, tal final es la paradoja trágica de la venganza como fracaso triunfante. 
impiedad de su muerte (1382-1383), él morirá de la peor manera, frente a lo cual sólo le resta a Jasón lamentarse (1393-1395) e invocar a la Erinia (1389), a la Justicia (1390) y a Zeus (1405).

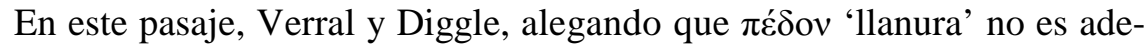
cuado para aludir al hábitat del monstruo, suprimen el verso 1359:

y [1lámame] Escila, la que habitó la llanura tirrénica

Bien señala Rodríguez Adrados ${ }^{57}$ que puede haber alguna corrupción en ese vocablo o que, simplemente, "llanura tirrénica" aluda a toda Italia, en general; se trataría, pues, de una sinécdoque poética.

Bothe, seguido por Méridier, condenó el verso 1387, que es una aclara-

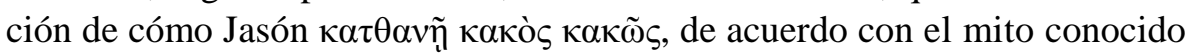
(lo habría golpeado el mástil de la nave):

golpeado en tu cabeza por un resto de la Argo

tras ver los amargos finales de mis ${ }^{58}$ bodas (1387-1388)

Rodríguez Adrados no hace referencia a esta propuesta. Pensamos que tampoco hay razones de peso para eliminar el verso: para Bothe es aclaración excesiva y le parece espurio que haya dos participios en versos sucesivos

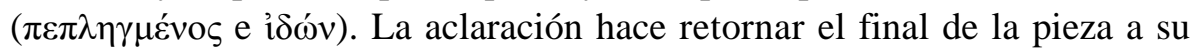
primer verso, que menciona la Argo, y los participios se refieren a dos momentos diversos cronológicamente, de modo que la muerte poco heroica de Jasón será adecuada culminación de su frustrado matrimonio. La venganza de Medea, construida gradualmente, tendrá de tal manera un apéndice futuro.

Nos resta analizar cómo dos imágenes tienen vinculación con la venganza, tanto en su motivación, como en el conflicto que ocasiona y en su concreción. Son imágenes que surgen, por un lado, de vocablos referidos al áni-

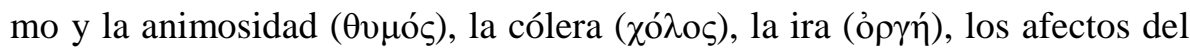
corazón ( $\kappa \varepsilon ́ \alpha \rho, \kappa \alpha \rho \delta i ́ \alpha, \kappa \rho \alpha \delta i ́ \alpha)$; y que surgen, por otro, del uso del vocablo mano ( $\chi \varepsilon i ́ \rho)$ o diestra $\left(\delta \varepsilon \xi \xi_{1}\right)$. Este último aspecto ha sido reiteradamente mencionado y particularmente estudiado por Flory.

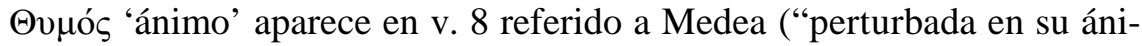
mo"), en 865 'ánimo paciente', 1056; al coro en 637 ("golpeando mi ánimo"), a Creonte en 310; tiene el valor de 'animosidad / animadversión' en $108,879,883,1079$, referidos a Medea y en 1152 a la princesa.

57 Ibidem.

58 "Mis" sigue la lección de los manuscritos y no la enmienda véov 'nuevas': Medea se refiere a cómo concluyó su matrimonio. 


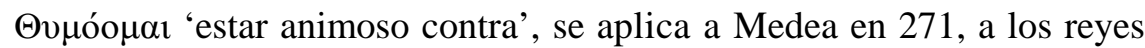
en 455 .

$\Delta v \sigma \theta 0 \mu о v \mu \varepsilon ́ v \eta ̣ 91$ 'mal animosa', se refiere a Medea.

$\Delta v \sigma \theta v \mu i ́ \alpha 691$ 'mal ánimo', referido a Medea.

Bapv́$\theta v \mu$ o 176 'de profunda animosidad', califica la ira de Medea.

Прó $\theta v \mu$ о 179 ‘benevolente’ es el coro, Egeo en 720; “ardorosa” Medea en 485 , la princesa en 1146.

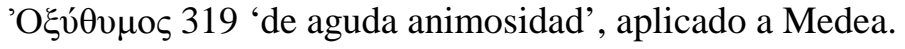

Vemos, pues, que predomina la idea de una mala disposición anímica y notoriamente centrada en Medea. También observamos que estos usos cesan en 1079, es decir, al final del quinto episodio, una vez que Medea concluye su conflicto interior y decide el filicidio.

En cuanto a ỏ $\rho \gamma \eta$ 'ira', aparece en 121 en alusión a los reyes, incluida Medea, que es princesa; referida a Medea en 176, 447, 520, 615, 870, 909; referida a los reyes en 456; al coro en 637; a la princesa en 1150; con la idea de 'castigo' ocurre en 129 y 1152, referidas a la divinidad. Por lo tanto, también la ira se aplica predominantemente a Medea y aparece así hasta 909.

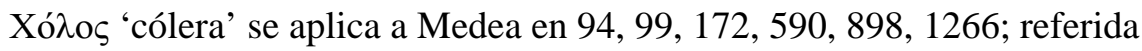
a la princesa en 1150. También esta idea predomina en el personaje central y su uso concluye en 1266, inmediatamente antes del filicidio.

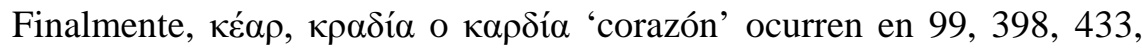
$590,858^{59}, 911,1042,1242$ aplicados a Medea; al hombre en general en 245; a Jasón en 1360. Es claro que estos vocablos se refieren principalmente a la heroína y que concluye la aplicación a ella cuando Medea anuncia que cometerá filicidio.

Sobre la base de este análisis, pensamos que estos vocablos apuntan a expresar el sentimiento de Medea, su afección, que la motiva a la venganza, y el conflicto que ello le produce cuando incluye a los hijos como instrumento. Este aspecto se desarrolla hasta el momento del filicidio ${ }^{60}$. Poco antes, la ira pasa a la princesa, a quien disgusta como madrastra ver los hijos ajenos, y la afección del corazón se traslada a Jasón una vez ocurridas las muertes.

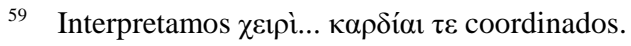

60 Como observó de Romilly 1973 p. 130, la pasión moviliza, la pasión genera desig-

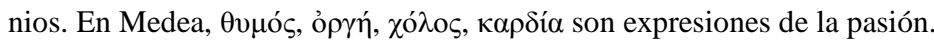


En cuanto a la $\chi \varepsilon \varphi^{\prime}{ }^{61}$, aparece como $\delta \varepsilon \xi 1 \alpha$ 'diestra' ( $\left.\sin \chi \varepsilon i ́ \rho\right)$ en 21 y en 1365; en el primer caso son las manos de Jasón y Medea que hicieron el pacto matrimonial; en el último, es la diestra Jasón, que se exime del asesinato. Además, tenemos $\chi$ cíp en 4 referida a los argonautas; en 335 a los guardias del rey; en 370 pueden ser las manos de Medea que imploran a Creonte o las manos de éste que reciben la súplica; se refiere a la mano de Medea tomada por Jasón en 496; a la mano "dadivosa" de Jasón en 612 y en 939, castigadora en 1320 y 1322, dispuesta a sepultar a los niños en 1412; a las manos de los niños en 784, 956, 1034, 1070, 1071, 1141; a las de ellos y su padre en 899; a la mano criminal de Medea en 857, 864, 959 (cuando entrega los regalos), 1055, 1244, 1254, 1273, 1309, 1378 (para el entierro de los niños); a la mano de la princesa en 973, 981, 1003; a los corintios en

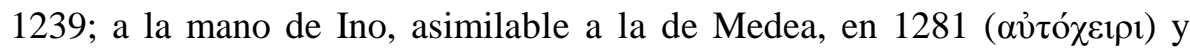

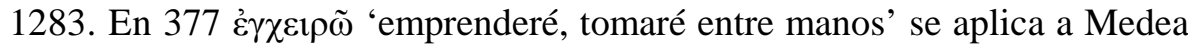

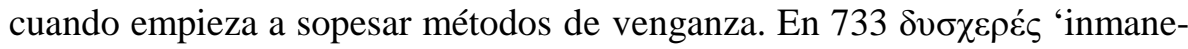
jable' es el asunto que tiene Medea, según Egeo. De este recuento se desprende que, en contrario a los vocablos que tienen que ver con la motivación y el conflicto, 'mano' se hace más frecuente en la segunda mitad de la pieza; se refiere a la mano criminal de Medea en nueve ocasiones (once si le sumamos la figura de Ino) y todas a partir de 857, después de revelar su plan inicial; sus usos se mezclan con los referidos a las manos de los niños, usados por ella como instrumentos de la venganza, y a los relativos a la princesa, que acoge los dones como víctima de la venganza. Si primero la mano prevalece como signo de pacto, súplica y afecto, gradualmente va tomando el valor de signo de crimen, de hecho que se va consumando y que lleva a una ruptura total: Jasón no puede tocarla a ella ni a los niños $(1320,1412)^{62}$.

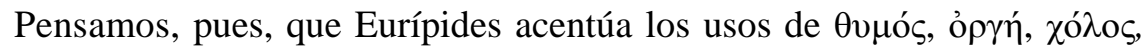
$\kappa \alpha \rho \delta i ́ \alpha$ en la primera parte de la obra para orientarlos a establecer la motivación de la venganza y el conflicto que ella genera; en cambio, acentúa en

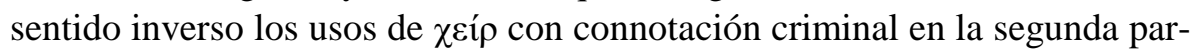
te, para connotar que, justificada la motivación y resuelto el conflicto, se con-

61 No tenemos en cuenta la enmienda $\chi \varepsilon \rho o ́ \varsigma$ de Wilamowitz en 339, ni la variante $\chi \varepsilon ́ \rho \alpha \varsigma$ en 1206 frente a $\delta \varepsilon ́ \mu \alpha \varsigma$, que parece más adecuada para justificar que Creonte sea presa de los venenos (1212-1217).

62 Dice Bordaux 1996 p. 176 que la mano abusada abusa, la mano traicionada traiciona. Para Menu 1996 p. 122, que Jasón no pueda tocar es indicio de su participación del no-ser mientras que Medea recuperó su ser. 
creta la venganza ${ }^{63}$. En ambos casos Medea concentra el mayor número de referencias. Los niños, en cambio, están presentes o aludidos a todo lo largo de la pieza, como fuente de dolor, objeto de amor, interés paterno, motivo de compasión, instrumento de venganza: están indirectamente vinculados con la traición de Jasón y la deshonra de Medea pero pasan a ser directo recurso de venganza contra esa traición y de reparación de la honra injuriada.

Como bien ha señalado Bordaux ${ }^{64}$, Medea no dice qué va a hacer (salvo en 793 ss.) sino que simplemente lo hace y así Eurípides nos muestra su plan en acción, representa los movimientos secretos de Medea antes de decirlos: no dice "ahora voy a conseguirme un refugio aliándome con Egeo"; simple y eficazmente lo va concretando y mostrando en la escena. Pero este "hacer la venganza" no es un plan preconcebido en todas sus partes, sino que se va construyendo gradualmente a medida que los acontecimientos se van dando favorables. Pruebas claras de ello es que aparezca Egeo, persona no prevista por Medea pero que responde a sus esperanzas y resulta fundamental para dar lugar a la venganza (pues Medea no quiere quedar ni prisionera ni muerta), y que Creonte se abrace a su hija de modo que muera también él. Medea sabe desde un comienzo que quiere vengarse, que necesita restaurar su $\tau \imath \mu$ ́ ultrajada; pero no sabe si lo hará, al modo de Ayante, mediante el suicidio o matando a su marido, o a los reyes, o a los tres, o si dejando a Jasón sin hijos y sin posibilidad de ellos; no sabe si le conviene matar con fuego, con espada o con venenos. El resultado es una mezcla de estas posibilidades: el matar a sus hijos es en parte una forma de suicidio; hacerlo es mejor castigo contra Jasón que matarlo a él mismo físicamente; para dejar a Jasón sin posibilidad de hijos, debe matar a la princesa, con lo cual se venga a la vez de ella y de su padre el rey; la muerte del rey le viene por añadidura. La venganza, pues, se va construyendo gradualmente, superando dudas y a medida que se van presentando situaciones ventajosas e inesperadas; las imágenes del corazón y sus sentimientos construyen la motivación y la justificación de la venganza y señalan el conflicto hasta la toma de decisión, de modo que se dé lugar, a su tiempo, a la concreción de la venganza, denotada por las imágenes de la mano que pasan de suplicantes y acariciadoras a transmisoras de muerte: a medida que decrecen los usos de las imágenes de sentimiento cre-

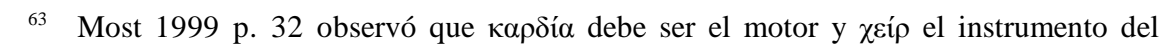
asesinato.

64 Bordaux 1996 p. 177. 
ce también gradualmente el uso de la imagen de la mano vengadora; el protagonismo de Medea también tiene una graduación: pasa de oculto a manifiesto y va creciendo, en presencia y poder, hasta un final en el que lo humano del personaje queda en un segundo plano, prevaleciendo la epifanía del poder divino; el protagonismo aludido de 1251-1316 es un ocultamiento aparente, en el cual Medea es más que nunca, aunque invisible y silente, el eje de la acción y prepara su reaparición triunfante.

En este proceso, los pasajes aquí analizados y cuestionados por la crítica en cuanto a su autenticidad resultan no sólo defendibles sino necesarios para establecer esa graduación que se verifica en la estructura interna, en las imágenes y en la construcción del crimen.

\section{BIBLIOGRAFÍA CITADA}

ARNOTT, G. 1973: «Euripides and the unexpected», $G \& R$ 20-1, pp. 49-64.

ARNOTT, G. 1984-5: «Alcune osservazioni sulle convenzioni teatrali dei cori euripidei», Dioniso 55, pp. 147-155.

BoEDEKER, D. 1997: «Becoming Medea. Assimilation in Euripides», en J. Clauss- S. Johnston edd. Medea, New Jersey, Princeton University Press, pp. 127-148.

BordauX, L. 1996: «Quelques remarques sur Euripide, homme de théâtre dans Médée», Pallas 45, pp. 169-179.

Borges BELCHIOR DA FONSECA, I. 1987: «O divórcio no direito ático», Cultura clássica em debate, Belo Horizonte, Universidade Federal de Minas Gerais, pp. 103-111.

BREMmer, J. 1997: «Why did Medea kill her brother Apsyrtus?», en J. Clauss- S. Johnston edd. Medea, New Jersey, Princeton University Press, pp. 83-100.

BUIS, E. 2001: «Matrimonios en crisis y respuestas legales: el divorcio unilateral o de común acuerdo en el derecho ateniense», Buenos Aires, Facultad de Filosofía y Letras, inédito.

CiтTI, V. 1996: «Médée et le problème du tragique», Pallas 45, pp. 47-55.

Collinge, N. 1962: «Medea ex machina», CPh 57-3, pp. 170-172.

FARTZOFF, M. 1996: «Le pouvoir dans Médée», Pallas 45, pp. 153-168.

FLORY, S. 1978: «Medea's right hand: promises and revenge», TAPA 108, pp.69-74.

GonZÁleZ DE ToBiA, A. 1983: «Doble lógos en Medea», Argos 7, 101-112.

GUELERMAN, C. 1997: «El agón más grande», AFC 15, 118-128. 
JouAn, F. 1996: «Qui a peur de Médée?», Pallas 45, 87-97.

KovaCs, D. 1993: «Zeus in Euripides' Medea», AJPh 114, 45-70.

LÓPEZ-FÉrEZ, J. 1996: «Sophía-sophós dans la Médée d' Euripide», Pallas 45, pp. 139-151.

MARTINA, A. 1993: «Struttura e spazio scenico nella Medea di Euripide», en R. Pretagostini, Tradizione e innovazione nella cultura greca da Omero all'età ellenistica, Roma, pp. 577-590.

Mattiace, M. T. 1993: «La violenza verbale nel teatro di Euripide», Dioniso 63-1, pp. 47-57. Melero, A. 1996: «Les autres Médées du théâtre grec», Pallas 45, pp.57-68.

Menu, M. 1996: «Medée entre 'avoir' et 'être'», Pallas 45, pp. 111-125.

MÉRIDIER, L. 1947: Euripide, tome I. París.

Moreau, A. 1996: «Médée, bouc émissaire?», Pallas 45, pp. 99-110.

Most, G. 1999: «Two problems in the third stasimon of Euripides' Medea», $C P h$ 94-1, pp. 20-35.

NANCY, C. 1984: «Euripide et le parti des femmes», QUCC 17, pp. 111-136.

PAGE, D. Euripides, Medea, Oxford, 1938, ${ }^{2} 1952$.

RANGER, J. 1996: «Violence, nature et divin chez Médée», Pallas 45, pp. 229-249.

REEVE, M. 1972: «Euripides, Medea 1021-1080", CQ 22-1, pp. 51-61.

REINHARDT, K. 1972: «La crise du sens chez Euripide», en Eschyle. Euripide, París.

RODRÍGUEZ ADRADOS, F. 1993: «Notas críticas a Eurípides, Medea», EM 61-2, pp. 241-266.

RODRÍGUEZ CIDRE, E. 1997: «Lechos y lechos: análisis de algunas diferencias significativas en la Medea de Eurípides», AFC 15, pp. 248-269.

RODRÍGUEZ CIDRE, E. 1998: «El ver en la nodriza de la Medea de Eurípides: acerca de algunas reificaciones y animalizaciones», Mora 4, pp. 65-71.

RODRÍGUEZ CIDRE, E. 2000: «Mujeres deshonradas: injuria y traición en la Medea de Eurípides», AHAM 33, pp. 37-57.

ROMILLY, J. DE. 1973: La tragédie grecque, París.

SCHAMUN, M. C. 2001: «Agòn lógon en Medea de Eurípides, vv. 446-626», Synthesis 8, pp. 137-153.

SEAFORD, R. 1990: «The structural problems of marriage in Euripides», en A. Powell ed. Euripides' women and sexuality, Londres, pp. 151-176.

Segal, CH. 1996: «Euripides' Medea: vengeance, reversal and closure», Pallas 45, pp. 15-44.

SEGAL, CH. 1997: «On the fifth stasimon of Euripides' Medea», AJPh 118, pp. 167-184.

SNELL, B. 1965: Las fuentes del pensamiento europeo, Madrid (orig. 1963).

STEVENS, P. 1956: «Euripides and the Athenians», JHS 76, pp.87-94.

SzTulman, H. 1996: «Le mythique, le tragique, le psichique: Médée. De la déception à la dépression et au passage à l'acte infanticide chez un sujet état-limite», Pallas 45, pp. 127-136. 